\title{
Clausal Ellipsis in Jibbali: The Case of Sluicing
}

\author{
Ali Algryani ${ }^{1}$ \\ ${ }^{1}$ Department of English Language and Literature, College of Arts \& Applied Sciences, Dhofar University, Salalah, \\ Oman \\ Correspondence: Ali Algryani, Department of English Language and Literature, College of Arts \& Applied \\ Sciences, Dhofar University, Salalah, Oman. E-mail: aalgryani@du.edu.om
}

Received: August 24, $2020 \quad$ Accepted: October 2, $2020 \quad$ Online Published: October 28, 2020

doi:10.5539/ijel.v10n6p361 URL: https://doi.org/10.5539/ijel.v10n6p361

\begin{abstract}
This study investigates the syntax of sluicing in Jibbali from a generative perspective to identify its morphological and syntactic properties. It also seeks to provide an explanation for the preposition stranding sluices that seem to violate of the Preposition Stranding Generalization (PSG) posited by Merchant (2001). The study concludes that sluicing exists in Jibbali and that it results from an overt wh-movement operation plus IP ellipsis at PF. Furthermore, it is argued that Jibbali sluicing allows for two sources of clausal ellipsis, referred to herein as sluicing and pseudosluicing. Both sluicing and pseudosluicing are derived by wh-movement and TP deletion despite the fact that sluicing stems from regular wh-questions, whereas pseudosluicing derives from a copular underlying source, i.e., cleft wh-questions. With regards to preposition-less (P-less) sluices, it is argued that such sluices are instances of pseudosluicing and that they do not involve preposition stranding as wh-movement in pseudosluicing proceeds from Spec TP. The proposed analysis for both forms of clausal ellipsis rests upon two arguments: a) the analysis of pronouns in the elided clause as copular pronouns, and b) the restriction on clefting non-nominal expressions in Jibbali which mirrors the parallelism between P-less sluices and cleft wh-questions in the language.
\end{abstract}

Keywords: clausal ellipsis, sluicing, pseudosluicing, preposition stranding, wh-movement

\section{Introduction}

\subsection{The Jibbali Language}

Jibbali is a Semitic language spoken in the south of Oman in coastal towns such as Salalah, Mirbat, Taqah, Hasik and the nearby mountainous areas. The language belongs to the family of Modern South Arabian (MSA) languages, which include six Semitic languages. These are Merhri, Jibbali (also known as Shahri, Śheri, or Śheret), Hasusi, Hobyot, Soqoțri and Batḥari, which are spoken in the eastern parts of Yemen and western Oman except Soqotri which is mainly spoken in the Yemeni island of Soqotra (Rubin, 2010, 2014). Jibbali, as pointed out by Rubin (2014), is spoken by approximately $30-50$ thousand inhabitants. It is worth noting that these languages have no writing traditions (Rubin, 2010).

Jibbali has three main varieties or dialects, namely Eastern, Central and Western Jibbali (Johnstone 1981; Rubin, 2014) (Note 1). This division is based geographically on the regions in which Jibbali is spoken. The three varieties are, to a great extent, mutually comprehensible and intelligible. The differences between these varieties lie in differences in pronunciation, lexis and morphology. For instance, as far as pronunciation is concerned, the phoneme $/ \mathrm{g} /$ is pronounced as [d] 3 by both central and eastern Jibbali speakers and as [g] by western Jibbali speakers (Rubin, 2014).

\subsection{Clausal Ellipsis in Jibbali}

Ellipsis is a linguistic phenomenon that involves omitting elements that can be recovered from the context. There are several forms of ellipsis such as NP ellipsis, VP ellipsis and IP ellipsis. The current study is concerned with one type of clausal ellipsis referred to in syntactic theory as sluicing. Sluicing is a kind of clausal ellipsis in which a wh-question is reduced phonologically to a mere wh-phrase, which is understood as a fully-fledged wh-interrogative clause, as exemplified in (1) from English.

(1) John visited someone, but I don't remember who.

The remnant wh-phrase 'who' in (1) is interpreted as a full wh-question, i.e., 'who John visited' although what is 
pronounced is only the displaced wh-expression. Jibbali exhibits structures like (1) above, and they are interpreted by native speakers of the language as complete wh-questions. Example (2) is a sluicing structure from Jibbali.

\section{(2) Salim}

$$
\begin{array}{llllll}
\text { Salim } & \text { tatam } & \text { doftar don al-edSak mit lo } & \text { lo } \\
\text { Salim } & \text { bought.3MS } & \text { bookbut } & \text { NEG-know.1S } & \text { when } & \text { NEG. }
\end{array}
$$

'Salim bought a book, but I don't know when.'

The current study attempts to provide the first investigation into the syntax of sluicing in Jibbali. It aims to identify the morpho-syntactic properties of Jibbali sluicing (JS) and propose an analysis for this elliptical structure. The data used in the study was collected from native speakers of Jibbali in the governorate of Dhofar in the south of Oman. The informants are university students majoring in English Language, Translation Studies and engineering. The data obtained from informants was grammatically judged and elicited. All sentences used in the study were transcribed, glossed and translated into English.

The study consists of six sections. The first section is an introduction to the study. It provides background information on Jibbali, the kind of clausal ellipsis dealt with in this study, the aims, methodology and organization of study. Section 2 discusses sluicing in syntactic theory and reviews previous studies on sluicing with a special reference to Semitic languages. Section 3 is concerned with wh-question formation in Jibbali. Section 4 investigates sluicing in Jibbali and attempts to determine its properties and underlying source with a special reference to the interaction between sluicing and preposition stranding. Section 5 puts forward an analysis for Jibbali sluicing constructions. Finally, section 6 concludes the study.

\section{Previous Studies on Sluicing: A Cross-Linguistic Perspective}

The term 'sluicing' was first coined by Ross (1969) and has been revived in Merchant's (2001) seminal work on sluicing. Merchant's (2001) work on sluicing provided the first comprehensive investigation of sluicing arguing that the sluiced clause contains an invisible syntactic structure of a full wh-question. Based on cross-linguistic morpho-syntactic properties of sluicing such as morphological case matching and preposition stranding, Merchant (2001) concludes that sluicing results from a wh-movement operation plus IP deletion at PF. In addition, Merchant (2001) opposes assimilating sluicing to reduced wh-clefts as both structures are distinct.

Sluicing constructions have been investigated in several languages such as Japanese (Shimoyama, 1995), Dutch (Craenenbroeck, 2010a), Indonesian (Sato, 2011), Spanish (Rodrigues et al., 2009), Mandarin Chinese (Adams \& Tomioka, 2012), Libyan Arabic (Algryani, 2012), Emirati Arabic (Leung, 2014a) and Saudi Arabic (Alshaalan $\&$ Abels, 2020). The central issue of these studies was to uncover the internal syntax of sluicing and determine its morpho-syntactic properties.

To start with, Shimoyama (1995) and Kuwabara (1996) studied sluicing in Japanese and concluded that sluicing is a form of an elliptical wh-cleft. Similarly, Mandarin Chinese has been analysed as pseudosluicing in which the elided material is considered a phonologically empty category (Adams \& Tomioka, 2012). The proposed analysis for Mandarin sluicing captures some language-specific properties such as the requirement of overt correlates to refer to argument wh-phrases, the use of copulas and finally island amelioration under ellipsis.

Regarding research on sluicing in Semitic languages, sluicing has been investigated in some modern varieties of Arabic including Libyan Arabic (Algryani, 2012), Emirati Arabic (Leung, 2014a) and Saudi Arabic (Alshaalan \& Abels, 2020). Algryani's (2012) study of sluicing revealed that sluicing is manifested in the Libyan variety of Arabic and that it stems from wh-movement plus IP ellipsis at PF. More importantly, it is argued that sluicing in the language does not violate the Preposition Stranding Generalization (PSG) as prepositionless (P-less) sluices derive from cleft interrogative clauses that do not involve wh-movement from a clause-internal position. The implication of this sluicing property, which has also been attested in other languages, provides evidence that there are two distinct forms of elliptical wh-interrogative clauses and that both are derived via movement and deletion.

Leung (2014a) investigated Emirati Arabic sluicing constructions and found out that they result from wh-movement plus clausal deletion. The study further points out that the underlying source and typology of sluicing are predetermined by the modes of wh-interrogatives available in the language. In another work, Leung (2014b) argues that sluicing in Emirati Arabic violates Merchant's (2001) PSG in the sense that while preposition stranding (p-stranding) is strictly disallowed in the formation of wh-interrogatives, it is allowed in sluicing. In his account for P-less sluices in Emirati Arabic, Leung (2014b) argues that the p-stranding effects can be repaired at PF, i.e., repaired by ellipsis. 
Alshaalan and Abels (2020) studied Saudi Arabic sluicing with a special focus on p-stranding sluices. They concluded that the ellipsis site in sluicing contains a syntactic structure and that sluicing is derived by wh-movement and clausal deletion. However, with respect to P-less sluices, they argue that they can stem from a cleft source or a resumptive wh-question. Such as a conclusion is problematic for Merchant's (2001) PSG as P-less sluices in the language can derive from a non-copular source, which constitutes a violation to the PSG.

Given that sluicing is a form of elliptical wh-questions, the next section discusses the formation of wh-questions in Jibbali as this will provide more insights into understanding the syntax of wh-movement and sluicing constructions in the language.

\section{The Formation of Wh-Questions in Jibbali}

Jibbai has three main forms of wh-questions, namely regular, cleft and in-situ wh-questions. The language has a number of nominal and non-nominal wh-words such as mun 'who', inəh 'what', inəh mən, incn 'which', hun, hutun 'where', mit 'when', ksh 'why', yol, ysh 'how', and $m t \varepsilon$ 'how many/much' (Rubin, 2014). All these wh-words are used to form wh-questions.

In regular wh-interrogatives, the wh-word surfaces clause-initially and is marked by a gap bound by the fronted wh-expression, as illustrated in (3) and (4). Regular wh-questions, which involve fronting the wh-phrase, can be formed by both argument wh-expressions and wh-adjuncts.

(3) mun zahəm?

who came.3MS

'Who came?'

(4) inah ttatam Suhail?

what bought.3MS Suhail

'What did Suhail buy?'

It has been proposed in previous studies on wh-movement in Semitic languages (e.g., Bakir, 2017; Aoun et al., 2010; Shlonsky, 2002 among others) that wh-fronting is a result of an overt wh-movement process to a clause-initial position. Such an argument is based on a set of diagnostic tests referred to as syntactic islands, i.e., syntactic configurations out of which extracting a wh-phrase is not permissible. For instance, examples (5) and (6) are ungrammatical because they involve extracting the wh-phrase mun 'who' from a relative clause island and an adjunct clause island respectively.
(5) *mun $_{i} \quad$ tyorb

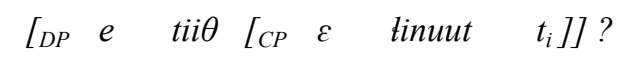
who know.2sM
DEF woman
REL saw.3SF

'*Who do you know the woman who saw?' (Bakir, 2017, p. 52)
(6) *mun $_{i} \quad$ Jixbork
?aћmad
[CP her kuun
if was.3SM
lini $\left.t_{i}\right]$ ?
Who
Ahmad

'*Who did you ask Ahmad if he saw?' (Bakir, 2017, p. 52)

The formation of cleft wh-questions involves a clause-initial wh-phrase and a resumptive pronoun occupying the gap considered to be the position of the moved wh-phrase. The following are examples of cleft wh-questions.

(7) mun (ðวh) $\varepsilon$ zahəm?

who (he) REL. came.3MS?

'Who is it that came?'

(8)

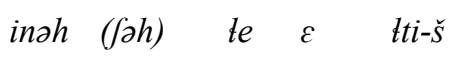
Suhail?
what (he) thingREL. bought.3MS-it Suhail

'What is the thing that Suhail bought?'
(9) inah te $\varepsilon$ tti-š Saed?
what thing REL. bought.3MS-it Saed
'What is it that Saed bought?'

There are some morpho-syntactic features that characterize cleft wh-questions. First, as the case in Semitic languages, e.g., Jibbali (Bakir, 2017), Libyan Arabic (Algryani, 2012), Egyptian Arabic Wahba (1984), 
Palestinian Arabic (Shlonsky, 2002) among others, these questions are marked by a clitic resumptive pronoun in the position assumed to be the place where the wh-phrase was first generated. Second, cleft wh-questions are only compatible with nominal wh-expressions; PP wh-phrases and wh-adjunct expressions are incompatible with such wh-questions, as in shown (10) and (11).
(10) *mit $\varepsilon \quad$ Salim zahəm?
when REL. Salem came.3MS

'When was it that Salem came? (Intended)

$\begin{array}{rllll}\text { (11) *ke mun } & \varepsilon & \text { herog } & \text { Salem? } \\ \text { with } & \text { whom } & \text { REL. talked.3MS } & \text { Salem }\end{array}$

'With whom was it that Salem talked?' (Intended)

Third, unlike regular wh-questions, cleft wh-questions are insensitive to island constraints, as evidenced in (12) and (13). The grammaticality of (12) and (13) suggests that this class of wh-questions does not involve wh-movement from a clause-internal position.
(12) Piine $\varepsilon$ mahaad
tini
$\left[\begin{array}{lllll}D P & e & \text { yiig } & \varepsilon & \left.\text { ttii- } \int\right]\end{array}\right]$
what REL Mahad
saw.3SM [ DEF man REL bought.3SM-him]

'*What is the thing that Mahad saw the man who bought it?' (Bakir, 2017, p. 55)
(13) muиn
$\varepsilon \quad$ saalim
$\begin{array}{ll}\text { Payad } & \text { C } P \\ \text { went.3SM } & {[}\end{array}$
efene
feh yetini-f]?
'*Who is the person that $\mathrm{S}$. went before seeing?' (Bakir, 2017, p. 55)

Finally, cleft wh-questions differ from regular wh-questions in that they permit pronouns to appear between the wh-word and the relativizer, as shown (14)
(14) $i n \partial h \quad\left(\int a h\right)$ te $\varepsilon \quad t i-\check{s}$
Suhail?
what (he) thing REL bought.3MS-IT Suhail
'What is the thing that Suhail bought?'

The last type of wh-questions is in-situ wh-questions in which the wh-word remains in the position it was first generated in. Such wh-questions are used in Jibbali and are normally perceived as echo wh-questions. The following are examples of in-situ wh-questions in the language.
(15) ttatam inah?
bought.3MS what
'He bought what?'
(16) herog ke mun?
Talked.3Ms with who
'He talked with whom?'
(17) zaham mit?
came.3MS when
'He came when?'

\section{Sluicing and Sluicing Typology in Jibbali}

Jibbali, a Semitic language spoken in southern Oman, exhibits a variety of sluicing constructions. Speakers of the language use various forms of elliptical wh-questions in main and embedded clauses. Below are two examples of Jibbali sluicing (JS).
(18) Salem ttatam
le,
don al-edhak inzh lo
Salem bought.3Ms
something but
NEG-know.1s
what NEG

'Salem bought something, but I don't know what'.
(19) Mahad zəhəm,
$\begin{array}{rll}\text { don, al-edSak } & \text { mit } \\ \text { but NEG-know.1MS } & \text { when }\end{array}$
lo
Mahad came.3MS
but NEG-know.1MS when NEG 
'Mahad came, but I don't know when.'

Different types of sluicing constructions are manifested in Jibballi. For instance, sluiced clauses can occur with overt correlates, implicit arguments, adjunct remnants, and contrastive elements. In the first type of sluicing, the wh-remnant refers back to a spelled-out correlate in the previous clause, as in (20). The correlate is normally indefinite and has to be of the same grammatical category as that of the remnant.

(20) Mahad tatam te $\quad$ don al-edSak inah lo
Mahad bought.3MS something but NEG-know.1s what
'Mahad bought something, but I don't know what'.

In the second type, the remnant refers to a null argument licensed by the argument structure of the verb, as in (21), whereas in the third, the wh-phrase of the sluice is an adjunct that does not refer to any expression in the antecedent clause, as in (22).

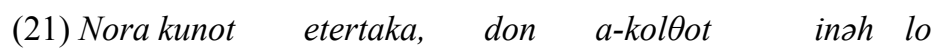

Nora was.3FS read.3Fs but NEG-said.3Fs what NEG

'Nora was reading, but she didn't say what'.

(22) Saed tatam sayyarzh don al-edSak mit lo

Saed bought.3MScar but NEG-know.1s when NEG.

'Saed bought car, but I don't know when'.

Finally, contrastive sluices involve a contrast in the content of the sluiced wh-phrase and that of its correlate in the previous discourse, as shown in (23).

(23) Saed tatam töt dofotrat don al-edGak mte: mglat lo.

Saed bought.3MS three books but NEG-know.1s how many magazine NEG

'Saed bought three books, but I don't know how many magazines'.

It is worth noting that Jiballi sluicing clauses share some properties attested in other languages. First, it is only licensed by interrogative wh-phrases, as shown in examples (24) and (25). Second, Jiballi sluicing allows the presence of a variety of non-wh-remnants such as pronouns and the negative particle 'lo'. This is also showed in (24) and (25) respectively. In (24), the sluice contains a non-wh-remnant which is the negative particle 'lo' (Note 2 ), and the sluice in (25) contains an optional pronoun in addition to the negative particle 'lo'.

(24) Saed tatam dofrat don al-edSak lo.

Saed bought.3MS books but NEG-know.1s how many NEG

'Saed bought books, but I don't know how many'.

$\begin{array}{rlllll}\text { (25) Mahad } & \text { tatam } & \text { te } & \text { don al-edSak inวh (fah) lo } \\ \text { Mahad } & \text { bought.3MS } & \text { something but NEG-know.1s what } & \text { (he) NEG }\end{array}$

'Mahad bought something, but I don't know what'.

Third, sluicing in Jibbali is island-insensitive in the sense that it allows remnants to be extracted out of island domains inside elided material(Note 3). Finally, despite the fact that Jibbali is a non-p-standing language under regular wh-movement, as illustrated in the contrast in (26) and (27), the language seems to permit preposition stranding under sluicing, as evidenced in (28). The issue of sluicing in p-stranding contexts will be discussed in detail in section 4.2 .

$\begin{array}{llll}\text { ka } & \text { mun } & \text { herog } & \text { Mahad? } \\ \text { with } & \text { whom } & \text { talked.3MS } & \text { Mahad }\end{array}$

'With whom did Mahad talk?'

$\begin{array}{ccc}\text { (27) *mun herog } & \text { Mahad } & \text { kə? } \\ \text { who talked.3MS Mahad } & \text { with } \\ \text { 'Who did Mahad talk with?' (Intended) } & \end{array}$

$\begin{array}{rlclllll}\text { (28) Mahad } & \text { herog } & \text { ko de: } & \text { don } & \text { al-edSak } & \text { mun } & \text { lo. } \\ \text { Mahad } & \text { talked.3MS } & \text { with someone } & \text { but NEG-know.1S } & \text { who NEG }\end{array}$


'Mahad talked with someone, but I don't know who'.

\subsection{Jibbali Sluicing: Sluicing or Pseudosluicing?}

Since Jibbali possesses two main types of wh-questions in addition to in-situ wh-questions, it seems plausible to assume that Jibbali sluicing derives from either regular or cleft wh-questions. In section, I attempt to determine whether the underlying source of Jibbali sluicing (JS) is regular or cleft wh-questions. It is worth noting that sluicing in some languages has been analysed as pseudosluicing (Note 4) despite its superficial appearance as sluicing. For instance, according to Shimoyama (1995) and Kuwabara (1996), Japanese sluicing is a form of an elliptical wh-cleft. Likewise, Adams and Tomioka (2012) analyse Mandarin Chinese as pseudo-sluicing (Note 5). Another alternative analysis of sluicing put forward by Ross (1969) and developed recently by Merchant (2001), argues that sluicing derives from regular wh-questions by wh-movement and clausal deletion at PF, as illustrated in (31). Such an analysis derives its strength from cross-linguistic morpho-syntactic properties of sluicing such as morphological case-matching, p-stranding and binding effects that sluicing constructions share with their non-elliptical counterparts. Such cross-linguistic observations provide evidence for assuming a structure in the ellipsis site of sluicing and thus deriving sluicing by movement and ellipsis (Note 6).

(31) Someone called Jane, but no one knows who ealled Jane $t_{i^{-}}$

Given that there are two types of wh-questions that involve overt wh-movement, Jibbali sluices are assumed to have two underlying sources. In this section, I test Jibbali sluicing in different contexts in order to determine whether what appears as sluicing can be analysed as sluicing or pseudo-sluicing, and the contexts in which both structures occur. To achieve this, I adopt some of Merchant's (2001) diagnostics which can determine the behaviour of the sluiced wh-phrase in sluicing and clefting contexts.

\subsubsection{Diagnostic 1: Sluicing with Adjunct Wh-Phrases}

Merchant (2000) observes that sluicing is different from pseudo-sluicing with respect to adjunct wh-phrases. While the former can be formed with adjunct wh-words, the latter is unattainable. This seems to be the case in Jibbali as sluicing with adjunct wh-phrases is acceptable, as shown in (32); however, cleft wh-questions with adjunct wh-phrases whether elliptical or non-elliptical are not grammatical, as evidenced in (33a) and (33b) respectively.

$\begin{array}{llllll}\text { (32) Salim } & \text { tatam } & \text { sayyarah } & \text { don al-edSak } & \text { mit } & \text { lo } \\ \text { Salim } & \text { bought.3MS } & \text { car } & \text { but neg-know.1s } & \text { when } & \text { NEG. }\end{array}$

'Salim bought a car, but I don't know when'.

$$
\begin{aligned}
\text { (33) a. *don al-edSak mit } \quad \text { foh } \\
\text { but NEG-know.1s when (COP) } \\
\text { 'but I don't know when it was'. (Intended) }
\end{aligned}
$$

(33) b. *mit fah tatam sayyarah?

when COP bought.3MS car

'When was it that he bought a car?' (Intended)

The data in (32) and (33) indicate that sluiced clauses with adjunct wh-remnants are genuine sluices, i.e. they derive from regular wh-questions. The pseudosluicing source is not available as illustrated in (33) as wh-phrases of adverbial functions (i.e. adjuncts) are not compatible with clefts wh-questions.

\subsubsection{Diagnostic 2: Sluicing with Implicit Arguments}

Implicit arguments, as pointed out by Merchant (2001), can differentiate between sluicing and reduced wh-clefts in English. While sluicing is perfectly fine with implicit arguments, reduced wh-clefts are ungrammatical. This seems not to be the case in Jibbali as both sluicing and elliptical wh-clefts are compatible with dropped arguments, as illustrated in (34) and (35)

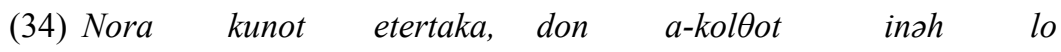
Nora was.3FS read.3FS but NEG-said.3FS what NEG
'Nora was reading, but she didn't say what'.

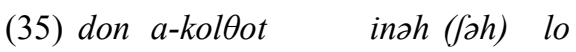
but NEG-said.3Fs what(he) NEG


'but she didn't say what'.

The conclusion that can be drawn from the above data is that there are two underlying structures, i.e. sources of derivation, for sluicing in implicit argument contexts. The possibility of spelling out the copular pronoun in the sluicing clause allows for an underlying copular source.

\subsubsection{Diagnostic 3: Language Clefting Strategy}

This test is used to determine whether there are restrictions on clefting certain grammatical categories in a language as this can help in distinguishing between sluicing and pseudosluicing. In this respect, it seems that Jibbali has restrictions on clefting non-nominal constituents, as evidenced in (36) below, which involves clefting a prepositional wh-constituent, and (37), which involves the use of a copular pronoun in a sluiced clause with a PP wh-remnant.

\section{(36) *ka mun (fah) $\varepsilon \quad$ Salim herog? \\ with whom (he) REL Salim talked.3MS \\ 'With whom was it that Salim talked? (Intended)}

(37) Mahad herog ko de: don al-eḑak ko mun (*fah) lo.

Mahad talked.3MS with someone but NEG-know.1s with whom he NEG

'Mahad talked with someone, but I don't know with whom it was'. (Intended)

The contrast in (36) and (37) confirms that elliptical wh-questions with PP-remnants can only be cases of sluicing. The pseudosluicing scenario is excluded due to the restriction on clefting PP constituents in the language.

\subsection{Jibbali Sluicing in P-Stranding Contexts}

In his extensive cross-linguistic study of sluicing, Merchant (2001) observes that stranding prepositions is only permissible if it is allowed under wh-movement. Based on this observation, Merchant (2001) put forward the Preposition Stranding Generalization (PSG) stated below.

A language $\mathrm{L}$ will allow preposition stranding under sluicing iff $\mathrm{L}$ allows preposition stranding under regular wh-movement. (p. 92)

The PSG argues for deriving sluicing by wh-movement and clausal ellipsis at PF as such as analysis accounts straightforwardly for the parallelism between a sluice and its non-elliptical counterpart. For instance, English allows p-stranding under wh-movement, so it is possible to strand prepositions under sluicing. Thus, the P-less sluice in (38) is grammatical because it is assumed to derive from an available p-stranding wh-question, as in (39b).

(38) Mary went with someone, but I don't know who wath

(39) a. With whom did Mary go?

b. Who did Mary go with?

As mentioned earlier in section 4, it has been observed that Jibbali sluicing exhibits p-stranding effects although Jibbali is a non-p-stranding language under wh-movement, as illustrated in (40) and (41) respectively.
(40) Mahad herog
Mahad talked.3Ms
ka de:
don al-edSak
mun lo.
'Mahad talked with someone, but I don't know who'.
(41) a. ko mun herog Mahad?
with who talked.3Ms Mahad
'With whom did Mahad talk?'

$\begin{array}{clll}\text { b. *mun } & \text { herog } & \text { Mahad } & k ə ? \\ \text { who } & \text { talked.3MS } & \text { Mahad } & \text { with }\end{array}$
'Who did Mahad talk with?' (Intended)

Recent research has shown cases of P-less sluices in non-p-stranding languages such as Portuguese (Almeida \& Yoshida, 2007), Spanish (Rodrigues et al., 2009) and Arabic (Algryani, 2012) among others. These studies concluded that regardless of the apparent $\mathrm{p}$-stranding effects displayed by sluicing in these languages, such cases 
of P-less sluices do not derive from regular wh-questions but rather from a copular underlying structure. This confirms that sluicing in such languages is not a counterexample to the PSG. Furthermore, the findings of these studies provide evidence for the availability of an alternative source for elliptical wh-questions (Note 7). On the other hand, other studies on p-stranding sluices such as those of Sato (2011), Wang (2007) and Stjepanović (2008) for Indonesian, Mandarin Chinese and Serbo-Croatian respectively argue that these languages constitute counterexamples to the PSG as sluicing permits p-stranding. Given that a cleft source is not available as an underlying source for P-less sluices in these languages, Wang (2007) argues that P-less sluices resort to resumption, whereas Stjepanović (2008) argues that Serbo-Croatian P-less sluices involve preposition drop at PF. Accounting for the P-less sluices in Indonesian, Sato (2011) argues while some violations can be repaired at the phonology-syntax interface, violations that occur in the syntactic computation cannot be repaired.

\section{Analysis of Jibbali sluicing}

Building on Bakir's (2017) analysis of wh-questions in Jibbali, I assume that the wh-phrase in both regular and cleft wh-questions undergo wh-movement from a clausal internal position to the CP domain. Following this line of analysis, sluicing stems from regular wh-questions, and it is derived by movement of the wh-phrase to the $\mathrm{CP}$ layer followed by TP deletion at PF, as schematized in (42) below.

$\begin{array}{rlllll}\text { (42) Mahad } & \text { tatam } & \text { te } & \text { don al-edSak inah lo } \\ \text { Mahad } & \text { bought.3MS } & \text { something } & \text { but NEG-know.1s what NEG. }\end{array}$

'Mahad bought something, but I don't know what'.

[SPEC CP inəh-i $\left[\right.$ TPMahad tatam $\left.\left.t_{-i}\right]\right]$

As for JS under p-stranding, e.g., (43), the question is whether what appears p-stranding under sluicing is superficial or genuine p-stranding as this has significant implications on the analysis of sluicing in the language. There are two possible analyses of sluicing in p-stranding contexts in non-p-stranding languages. The first is that the p-stranding effects are apparent and what appears as sluicing is pseudo-sluicing, i.e. an elliptical wh-cleft and this form of ellipsis is distinct from sluicing despite the fact that it can be derived via movement and deletion (Vicente, 2008; Rodrigues et al., 2009; Algryani, 2012). The second possible analysis implies that sluicing permits p-stranding and thus violates Merchant's (2001) PSG (Stjepanović, 2008; Sato, 2011; Leung, 2014; Alshaalan \& Abels, 2020) In this section, I argue that Jibbali sluices with apparent p-stranding effects are instances of pseudo-sluicing and therefore the language cannot be considered a counter example against the PSG. This argument is built on some language-specific morpho-syntactic properties displayed by sluicing in the language.

$\begin{array}{llllrllll}\text { (43) Salim } & \text { herog } & \text { kə } & \text { de: } & \text { don } & \text { al-edfak } & \text { mun } & \text { (fah) lo. } \\ \text { Salim } & \text { talked.3MS } & \text { with someone but } & \text { NEG-know.1S } & \text { who he } & \text { NEG }\end{array}$

'Salim talked with someone, but I don't know who'.

First, JS under p-stranding permits the spell-out of pronouns, as shown in (43). This is also attested in cleft wh-questions, which are analysed as copular clauses, i.e. cleft wh-questions, as exemplified in (44). The analysis of such wh-questions as cleft wh-questions rests upon some evidence that shows close resemblance between the two structures. Such wh-questions, for instance, contain a relative clause, a pronominal clitic and an optional copular pronoun, as in (44). I consider the admissibility of the presence of copular pronouns in sluicing as initial evidence for the proposed pseudosluicing analysis for P-less sluices.

\begin{tabular}{|c|c|c|c|c|}
\hline $\begin{array}{l}\text { mun (§h) } \\
\text { who (he) }\end{array}$ & $\begin{array}{c}\varepsilon \\
\text { REL }\end{array}$ & $\begin{array}{l}\text { Salim } \\
\text { Salim }\end{array}$ & $\begin{array}{l}\text { herog } \\
\text { talked.3MS }\end{array}$ & $\begin{array}{l}\text { sa-f? } \\
\text { with-him }\end{array}$ \\
\hline
\end{tabular}

It is worth noting that the pronouns that surface in the sluice are used to function as copulas. Jibbali, in this respect, patterns with other Semitic languages, e.g. Hebrew (Doron, 1983, 1986) and Arabic (Eid, 1991; Ouhalla, 1999; Shlonsky, 2002), in the use of pronouns to realize copula functions. For instance, Jibbali uses pronouns to achieve copula functions in equative clauses and cleft structures, as in (45) and (46) respectively.

$\begin{aligned} \text { (45) Muna } & \text { (sah)aSalmat. } \\ \text { Muna } & \text { (she) the-teacher }\end{aligned}$

'Muna is the teacher'.

(46) Mahad foh $\varepsilon$ tinik-tof. 
Mahad he REL saw.1s.him

'It is Mahad that I saw.' (Intended)

Second, given that regular wh-questions disallow p-stranding under wh-movement and that cleft wh-questions are incompatible with PP wh-expressions, as in (47a), which is mirrored in sluicing in p-stranding contexts, it is argued that P-less sluices, as in (43) above, can only have cleft wh-questions as an underlying source.
(47) a. *ko
$\begin{array}{llll} & \text { (Jh) } \varepsilon \text { Salim herog? } \\ \text { with whom (he) REL Salim talked.3MS }\end{array}$

'Who is that Salim talked with? (Intended)
b. mun
(fah) $\varepsilon$ Salim herog
sa- $\int ?$
who
(he) REL Salim
talked.3MS
with-him

'Who is that Salim talked with? (Intended)

Thus, for $\mathrm{p}$-stranding sluices, it is argued that such cases should be analysed as pseudo-sluicing, an elliptical cleft wh-question consisting of a DP, a copula and a headless relative clause functioning as a predicate. Pseudosluicing results from movement of the wh-phrase from Spec TP to Spec CP followed by clausal ellipsis, as shown in (49).

$\begin{array}{rlllllll}\text { (49) Salim } & \text { herog } & \text { ka } & \text { de: } & \text { don } & \text { al-edSak } & \text { mun } & \text { (Jh) lo. } \\ \text { Salim } & \text { talked.3MS with } & \text { someone } & \text { but } & \text { NEG-know.1s } & \text { who } & \text { (he) } & \text { NEG }\end{array}$

'Salim talked with someone, but I don't know who'

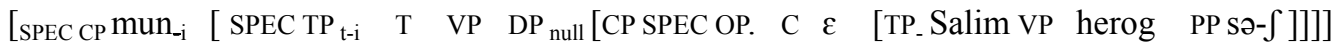

Given that wh-movement in pseudo-sluicing proceeds from Spec TP position, it is predicted, which is the case, that Jibbali sluicing constructions do not exhibit p-stranding effects. The deletion of the preposition with the relative clause gives rise to apparent $\mathrm{p}$-stranding effects.

\section{Conclusion}

The paper has discussed the ellipsis phenomenon of sluicing in Jibbali to identify its morpho-syntactic properties. The study concludes that sluicing in Jibbali is derived from regular wh-questions via wh-movement and clausal deletion at PF. With respect to p-stranding sluices, these are analysed as pseudo-sluices derived from copular clauses by wh-movement and deletion. As wh-movement in pseudosluicing proceeds from a clause-initial position, i.e., Spec TP, it follows that Jibbali sluicing is not a counterexample to the PSG as wh-movement does not involve p-stranding. The apparent p-stranding effects arise as a result of the deletion of the preposition with the headless relative clause leaving behind a remnant wh-phrase and an optional copular pronoun. Finally, the accounts put forward for sluicing and pseudo-sluicing explain some properties of Jibbali sluicing such as p-stranding effects, the presence of pronouns in the sluicing clause and the unavailability of pseudosluices with prepositional and adjunct wh-phrases in the language.

\section{References}

Adams, P. W., \& Tomioka, S. (2012). Sluicing in Mandarin Chinese: An instance of pseudo-sluicing. In J. Merchant \& A. Simpson (Eds.), Sluicing: Cross-linguistic perspectives (pp. 219-247). Oxford: OUP. https://doi.org/10.1093/acprof:oso/9780199645763.001.0001

Algryani, A. (2012). The syntax of ellipsis in Libyan Arabic: a generative analysis of Sluicing, VP ellipsis, stripping and negative contrast. PhD diss., Newcastle University. https://doi.org/10.5296/ijl.v5i5.4456

Almeida, D. A. de A., \& Yoshida, M. (2007). A problem for the preposition stranding generalization. Linguistic Inquiry, 38, 349-362. https://doi.org/10.1162/ling.2007.38.2.349

Alshaalan, Y., \& Abels, K. (2020). Resumption as a sluicing source in Saudi Arabic: Evidence from sluicing with prepositional phrases. Glossa: A Journal of General Linguistics, $5(1), 8$. https://doi.org/10.5334/gjgl.841

Aoun, E. J., Benmamoun, E., \& Choueiri, L. (2010). The Syntax of Arabic. Cambridge: Cambridge University Press. https://doi.org/10.1017/CBO9780511691775

Bakir, M. J. (2017). Wh-Questions in Jibbali. SKASE Journal of Theoretical Linguistics, 14(1), 8-63.

Chung, S., Ladusaw, W. A., \& McCloskey, J. (1995). Sluicing and logical form. Natural Language Semantics, 3, 
239-282. https://doi.org/10.1007/BF01248819

Craenenbroeck, J. v. (2010a). The syntax of ellipsis: evidence from Dutch dialects. Oxford: Oxford University Press. https://doi.org/10.1093/acprof:oso/9780195375640.001.0001

Craenenbroeck, J. v. (2010b). Invisible last resort: A note on clefts as the underlying source for sluicing. Lingua, 120, 1714-1726. https://doi.org/10.1016/j.lingua.2010.01.002

Doron, E. (1983). Verbless predicates in Hebrew. Ph.D. dissertation, University of Texas.

Doron, E. (1986). The pronominal copula as agreement clitic. In H. Borer (Ed.), The Syntax of Pronominal Clitics (vol. 19 of Syntax and Semantics, pp. 313-332). New York: Academic Press. https://doi.org/10.1163/9789004373150_014

Eid, M. (1991). Verbless Sentences in Arabic and Hebrew. In M. Eid \& B. Comrie (Eds.), Perspectives on Arabic Linguistics III (pp. 31-61). Papers from the Third Annual Symposium on Arabic Linguistics. Amsterdam: John Benjamins. https://doi.org/10.1075/cilt.80.05eid

Erteshik-Shir, N. (1977). On the Nature of Island Constraints. Bloomington, IN: Indiana University Linguistics Club.

Fukaya, T. (2012). Island-sensitivity in Japanese sluicing and some implications. In J. Merchant \& A. Simpson (Eds.), Sluicing: cross-linguistic perspectives (pp. 219-247). Oxford: Oxford University Press. https://doi.org/10.1093/acprof:oso/9780199645763.003.0007

Johnstone, T. M. (1981). Jibbali Lexicon. Oxford: OUP.

Kuwabara, K. (1996). Multiple wh-phrases in elliptical clauses and some aspects of clefts with multiple foci. Formal Approaches to Japanese Linguistics, 2(MITWPL 29), 97-116.

Leung, T. (2014a). Modes of interrogatives entail modes of sluicing: evidence from Emirati Arabic. In S. Farwaneh \& H. Ouali (Eds.), Perspectives on Arabic Linguistics XXIV-XXV (pp. 207-228). John Bejamins Publishing Company. https://doi.org/10.1075/sal.1.13leu

Leung, T. (2014b). The preposition stranding generalization and conditions on sluicing: Evidence from Emirati Arabic. Linguistic Inquiry, 45(2), 332-340. https://doi.org/10.1162/LING_a_00158

Merchant, J. (2001). The syntax of silence: Sluicing, islands, and the theory of ellipsis. Oxford: Oxford University Press.

Merchant, J. (2006). Sluicing. In M. Everaert \& H. van Riemsdijk (Eds.), The Blackwell Companion to Syntax (pp. 271-219). Blackwell Publishing. https://doi.org/10.1002/9780470996591

Merchant, J. (2008). Variable island repair under ellipsis. In K. Johnson (Ed.), Topics in Ellipsis (pp. 132-153). Cambridge: Cambridge University Press. https://doi.org/10.1017/CBO9780511487033.006

Ouhalla, J. (1999). Focus and Arabic Clefts. In G. Rebuschi \& L. Tuller (Eds.), The Grammar of Focus (pp. 335-359). Amsterdam: John Benjamins. https://doi.org/10.1075/la.24

Rodrigues, C., Nevins, A., \& Vicente, L. (2009). Cleaving the interactions between sluicing and preposition stranding. In L. Wetzels \& J. van der Weijer (Eds.), Romance languages and linguistic theory 2006 (pp. 175-198). John Benjamins, Amsterdam. https://doi.org/10.1075/cilt.303

Ross, J. R. (1969). Guess who? In R. I. Binnick, A. Davison, G. M. Green \& J. L. Morgan (Eds.), Papers from the fifth regional meeting of the Chicago linguistic society (pp. 252-286). Chicago: Chicago Linguistic Society, University of Chicago. https://doi.org/10.1016/0024-3841(71)90037-4

Rubin, A. (2010). A Brief Introduction to the Semitic Languages. NJ: Gorgias Press.

Rubin, A. (2014). The Jibbali (Shahri) Language of Oman. Leiden: Brill.

Sato, Y. (2011). P-stranding under sluicing and repair by ellipsis: why is Indonesian (not) special? Journal of East Asian Linguistics, 20, 339-382. https://doi.org/10.1007/s10831-011-9082-3

Shimoyama, J. (1995). On sluicing in Japanese. Ms., University of Massachusetts, Amherst.

Shlonsky, U. (2002). Constituent questions in Palestinian Arabic. In J. Ouhalla \& U. Shlonsky (Eds.), Themes in Arabic and Hebrew syntax (pp. 137-155). Dordrecht: Kluwer. https://doi.org/10.1007/978-94-010-0351-3_5

Stjepanovic, S. (2008). P-stranding under sluicing in a non-P-stranding language? Linguistic Inquiry, 39, 179-190. https://doi.org/10.1162/ling.2008.39.1.179 
Vicente, L. (2008). Syntactic isomorphism and non-isomorphism under ellipsis. Ms. UCSC.

Wahba, W. A. B. (1984). Wh-constructions in Egyptian Arabic. Ph.D dissertation, University of Illinois, Urbana.

Wang, C. A. (2007). Sluicing and resumption. In E. Elfner \& M. Walkow (Eds.), Proceedings of NELS 37 (pp. 239-252), Amherst, MA: GLSA Publications.

\section{Notes}

Note 1. Rubin (2014) also mentions that this classification corresponds to mountainous areas of three mountain ranges known in the region as Jabal al-Qamar (Western Jibbali), Jabal al-Qarā (Central Jibbali), and Jabal Samhāann (Eastern Jibbali).

Note 2. According to my informants, the negative particle 'lo' has two positions. It can occur right after the main verb as in (1), or at the end of the sentence, as in (2):
(1) al-eḑak lo mit
NEG-know.1s NEG when
(2) al-ediak
mit lo.
NEG-know.1s
when NEG

Note 3. This has been attested in a number of languages including English (Merchant, 2001, 2008), Japanese (Fukaya, 2012), Libyan Arabic (Algryani, 2012) and Emirati Arabic (Leung, 2014a) among others.

Note 4. It is worth mentioning that sluicing was analysed by Erteshik-Shir (1977) as a form of a reduced cleft structure, as schematized in (1):

(1) Someone sent me a gift, but I still don't know who was.

Merchant (2001) opposes such pseudo-sluicing of English sluicing and argues that it is different from sluicing as the latter derives from regular wh-interrogative clauses, not wh-clefts.

Note 5. It should be noted that linguists have also proposed that sluicing can have an alternative copular source as an underlying structure in p-stranding contexts, e.g., see (Cranenbroeck, 2010b; Vicente, 2008; Rodrigues et al., 2009 among others).

Note 6. Another structural theory that posits a structure, but argues against wh-movement, is the LF copying theory; the theory assumes that the elliptical clause contains a null category which is filled by copying the semantic content of the antecedent clause at LF (Chung, Ladusaw, \& McCloskey, 1995).

Note 7. Cranenbroeck (2010b) proposes the Invisible Last Resort condition which states that clefts can be used as a derivational source for sluicing only when a full regular wh-question is unavailable.

\section{Copyrights}

Copyright for this article is retained by the author, with first publication rights granted to the journal.

This is an open-access article distributed under the terms and conditions of the Creative Commons Attribution license (http://creativecommons.org/licenses/by/4.0/). 